\title{
The effect of dietary protein degradability and rumen inert fat supplementation on calf performance and veal production
}

\author{
C. W. Cruywagen", E. Lategan and L. C. Hoffman \\ Dept. of Animal Sciences, University of Stellenbosch, Stellenbosch, 7600, South Africa \\ E-mail: \#cwc@maties.sun.ac.za
}

\section{Introduction}

An estimated 176000 Friesian bull calves are born in South Africa annually. The theoretical potential veal production would be 17600 tonnes if these calves were to be slaughtered at around 190-200kg to produce a $100 \mathrm{~kg}$ carcass. Although there is a market for pink veal in South Africa, it is not utilised optimally, mainly because of a lack of knowledge by producers on calf rearing, but also due to consumer resistance, which could be ascribed to a lack of knowledge of veal as a source of quality meat. Traditionally, South African consumers prefer beef to veal. There is a growing public awareness of the benefits of low fat diets, and in this regard, veal could play an important role as a source of quality lean meat. Veal contains an average of $4 \mathrm{~g}$ of fat per $85 \mathrm{~g}$ cooked portion of trimmed loin steak compared to $8 \mathrm{~g}$ for lamb and beef and $9 \mathrm{~g}$ for pork. Leaner meats have more polyunsaturated structural fat and less saturated depot fat. Therefore, veal is low in both total and saturated fats (Moran et al., 1991). A study was undertaken to investigate the effect of dietary protein degradability and supplemental rumen-inert fats on body mass gain, feed intake and feed conversion ratios in veal calves, as well as digestibility coefficients, carcass masses and meat characteristics. Results on meat characteristics and fatty acid profiles are, however, not reported in this paper.

\section{Materials and Methods}

Six groups of six Friesian bull calves were used in the trial. All calves received a commercial milk replacer at 4 l/d for 42 days, followed by $2 \mathrm{l} / \mathrm{d}$ until weaning at 49 days of age. Starter diets as well as finisher diets differed between treatments in terms of protein degradability and the presence or absence of one of two rumen-inert fat sources. Two commercial fat sources were used, viz. Morlac ${ }^{\circledR}$ and Golden Flake ${ }^{\circledR}$, and included at $2.5 \%$ of the diet. Treatments were LD (low degradable protein), HD (high degradable protein), LD+m (low degradable protein with Morlac), HD+m (high degradable protein with Morlac), LD+gf (low degradable protein with Golden Flake), and HD+gf (high degradable protein with Golden Flake). These treatments applied for both the starter- and finisher diets. Dry matter and protein degradability values were determined in ruminally cannulated Holstein cows by an in sacco method where samples were incubated for $24 \mathrm{~h}$. Starter diets contained $18 \% \mathrm{CP}$ with degradabilities of $31 \%$ (LD) and 73\% (HD), and finisher diets contained 14\% CP with degradabilities of $22.5 \%$ (LD) and 56\% (HD). Starter diets were fed $a d$ lib. from day 14 until 10 weeks of age, and finisher diets were fed ad lib. from 11 to 20 weeks of age, when calves were slaughtered for veal production. All calves were used in a digestibility trial (using $\mathrm{Cr}_{2} \mathrm{O}_{3}$ as marker) during the finishing period. Data was analysed by ANOVA, using the GLM procedure of SAS (1988). Interactions between main effects occurred and these were divided into various sub-contrasts for further analysis.

\section{Results and Discussion}

Results for growth, feed intake and carcass parameters are presented in Table 1, and digestibility parameters in Table 2. The tables present general results, and because of interactions between main effects, final conclusions can not be made from the table values. Final results, obtained from further data analysis are, however, discussed here. There were no significant differences in body mass gain or dry matter intake over the entire 20 week period (Table 1). Feed conversion ratios (FCR) were improved significantly $(\mathrm{P}<0.04)$ when fat was supplemented to LD, but not to HD diets (Table 1). Dry matter- and fat digestibility values were only significantly higher $(\mathrm{P}<0.001)$ when fat was added to LD diets. Crude protein digestibility was significantly higher when fat was added to either the LD $(\mathrm{P}<0.001)$ or the HD $(\mathrm{P}<0.05)$ diets. The only significant difference $(\mathrm{P}<0.05)$ in carcass mass was that $\mathrm{HD}+\mathrm{m}$ calves realised lower carcass masses than $\mathrm{HD}+\mathrm{gf}$ calves. These calves also had the lowest body mass gain over the total trial period. 
Short paper and poster abstracts: $38^{\text {th }}$ Congress of the South African Society of Animal Science

Table 1 Body mass gain, DM intake and feed conversion ratio for the different experimental periods and carcass data for calves receiving diets differing in fat content and crude protein degradability.

\begin{tabular}{|c|c|c|c|c|c|c|c|}
\hline \multirow[t]{2}{*}{ Item } & \multicolumn{7}{|c|}{ Treatments } \\
\hline & LD & $\mathrm{HD}$ & $\mathrm{LD}+\mathrm{m}$ & $\mathrm{HD}+\mathrm{m}$ & LD+gf & $\mathrm{HD}+\mathrm{gf}$ & SEM \\
\hline \multicolumn{8}{|l|}{$\underline{\text { Starter diet }}$} \\
\hline \multicolumn{8}{|l|}{ Week 0-10 } \\
\hline Body mass gain $(\mathrm{kg})$ & 47.55 & 45.35 & 44.60 & 40.00 & 48.30 & 46.18 & 2.45 \\
\hline Total DMI (kg) & 114.21 & 108.18 & 102.67 & 98.76 & 111.88 & 110.90 & 4.80 \\
\hline FCR (DMI/kg gain) & 2.43 & 2.38 & 2.31 & 2.49 & 2.32 & 2.43 & 0.07 \\
\hline \multicolumn{8}{|l|}{$\underline{\text { Finishing diet }}$} \\
\hline \multicolumn{8}{|l|}{ Week $11-20$} \\
\hline Body mass gain $(\mathrm{kg})$ & 90.85 & 96.22 & 97.92 & 82.40 & 97.17 & 94.56 & 5.05 \\
\hline Total DMI (kg) & 311.02 & 328.33 & 300.38 & 313.93 & 292.82 & 323.66 & 14.95 \\
\hline FCR (DMI/kg gain) & 3.45 & 3.44 & 3.07 & 3.81 & 3.02 & 3.43 & 0.10 \\
\hline \multicolumn{8}{|l|}{ Total period } \\
\hline \multicolumn{8}{|l|}{ Week 0-20 } \\
\hline Body mass gain $(\mathrm{kg})$ & 138.40 & 141.57 & 142.52 & 122.40 & 145.47 & 140.74 & 6.12 \\
\hline Total DMI (kg) & 425.23 & 436.51 & 403.05 & 412.69 & 404.70 & 434.56 & 17.96 \\
\hline FCR (DMI/kg gain) & 3.09 & 3.09 & 2.83 & 3.38 & 2.79 & 3.08 & 0.07 \\
\hline Carcass mass (kg) & 88.42 & 92.75 & 92.25 & 80.80 & 90.33 & 91.00 & 2.88 \\
\hline Dressing \% & 49.44 & 50.98 & 50.53 & 48.98 & 48.13 & 49.62 & 0.63 \\
\hline
\end{tabular}

Table 2 Mean digestibility values calculated from the inert marker $\left(\mathrm{Cr}_{2} \mathrm{O}_{3}\right)$ used in the digestibility trial.

\begin{tabular}{|c|c|c|c|c|c|c|c|}
\hline \multirow{3}{*}{ Digestibility } & & & \multicolumn{4}{|c|}{ Fat source (rest) } & \multirow[b]{3}{*}{ SEM } \\
\hline & \multicolumn{2}{|c|}{ None } & \multicolumn{2}{|c|}{ Morlac } & \multicolumn{2}{|c|}{ Golden flake } & \\
\hline & LD & HD & LD & $\mathrm{HD}$ & LD & HD & \\
\hline DM & 61.74 & 65.91 & 75.44 & 69.00 & 75.54 & 67.15 & 2.48 \\
\hline $\mathrm{CP}$ & 61.44 & 61.60 & 71.33 & 68.23 & 75.44 & 66.12 & 2.20 \\
\hline $\mathrm{CF}$ & 33.66 & 37.43 & 53.87 & 42.51 & 32.91 & 24.92 & 4.04 \\
\hline FAT & 58.56 & 66.45 & 75.98 & 70.92 & 78.43 & 70.79 & 2.36 \\
\hline
\end{tabular}

\section{Conclusions}

Results would suggest a favourable effect of rumen inert fat supplementation on feed conversion ratio, but only when included in diets with low protein degradability. The effect appears to manifest only after 10 weeks of age, indicating the role of rumen activity. It should be economically viable to supplement starter and finishing diets with rumen inert fats. It appears as if the starter diet may contain higher degradable protein sources that are relatively inexpensive, but that low degradable protein becomes more important in the finishing period, after 10 weeks of age.

\section{References}

Moran, J., Hopkins, A. \& Warner, R., 1991. The production of pink veal from dairy calves in Australia. Outlook on Agriculture 20, 183-19

SAS, 1988. SAS/STAT User's Guide (Release 6.03). Statistical Analysis System Institute, Inc., Cary, NC, USA. 